ScIDice

\section{Comparison of Post Extraction Healing in Diabetic Patients with two different Blood Glucose Levels - A Case Control Study}

ISSN: $2377-8075$

Research Article

Aishwarya. $S^{1}$, Senthil Murugan. $\mathrm{P}^{2 *}$, Suresh. $\mathrm{V}^{3}$

${ }^{1}$ Saveetha Dental College and Hospitals, Saveetha Institute of Medical and Technical Sciences, Chennai - 600077 , TN, India.

${ }^{2}$ Associate Professor, Department of Oral and Maxillofacial Surgery, Saveetha Institute of Medical and Technical Sciences, Saveetha University, 162, Chennai - 600077, Tamil Nadu, India.

${ }^{3}$ Reader, Department of Prosthodontics, Saveetha Dental College and Hospitals, Saveetha Institute of Medical and Technical Sciences (SIMATS) Saveetha University, Chennai, India.

\title{
Abstract
}

Diabetes mellitus is a metabolic disorder characterised by an inability to regulate blood glucose level due to insulin deficiency or resistance. In dentistry, diabetics are considered to have increased healing problems related to dental extractions, periodontal surgery and wearing ill-fitting dentures. Therefore, management and treatment of diabetic patients undergoing oral surgical procedures are more difficult. Delayed angiogenesis, decrease in blood flow, compromised innate immunity, decrease in the production of growth factor and psychological stress have been reported as factors causing delay in the healing of extraction sockets in diabetic patients. So the aim of the study is to compare the post extraction healing in diabetic patients with two different glucose levels.It is a university setting retrospective study. The details of the 86,000 patient records were reviewed and analyzed, out of which 112 diabetic patients who had undergone extraction between June 2019 to March 2020 were included in this study after fulfilling inclusion and exclusion criterias. Age, gender, number of extractions, teeth number, blood glucose level $[<200 />200] \mathrm{mg} / \mathrm{dl}$, were included and evaluated. These datas were entered in SPSS. The data was analysed through chi square test.It was observed that there is a significant difference between post extraction healing and blood glucose levels among the diabetic patients.Within the limitations, patients with RBS level greater than $200 \mathrm{mg} / \mathrm{dl}$ had slower healing rate compared to patients with RBS level less than $200 \mathrm{mg} / \mathrm{dl}$.So this study will help the fellow dentists to be cautious in performing dental extractions in uncontrolled diabetic patients.

Keywords: Blood Glucose Level; Extraction Socket; Insulin Dependent Diabetes; Non Insulin Dependent Diabetes.

\section{Introduction}

Diabetes mellitus is a metabolic disorder characterised by an inability of the body to regulate blood glucose level due to insulin deficiency or resistance [19]. Type I diabetes or insulin dependent diabetes is characterised by deficiency of insulin production and Type II diabetes or non insulin dependent diabetes is characterised by relative insulin deficiency and tissue insulin resistance [16].

It is also characterised by abnormal carbohydrate, lipid and protein metabolism. As a result, this leads to hyperglycemia that causes microvascular complications and a variety of clinical neuropathic complications $[2,20]$. Studies have reported that half of the diabetic patients require surgery while the remaining two thirds of the patients who require surgery experience some complications relating to infection $[6,30]$.

The most common dental complications experienced by diabetic patients are due to extraction, periodontal surgeries and ill fitting dentures $[5,10]$. Some well known oral surgical complications include poor regeneration of soft tissues and delay in osseous tissue healing $[3,24]$. Diabetes is associated with increased skeletal complications such as lowering the bone mineral density and increasing the risk of bone fracture [51]. There is high level risk for osteopenia, osteoporosis, poor osseous healing, and impaired bone regeneration [41].

Mozatti M. et al reported, a delay in wound healing of oral ulcers

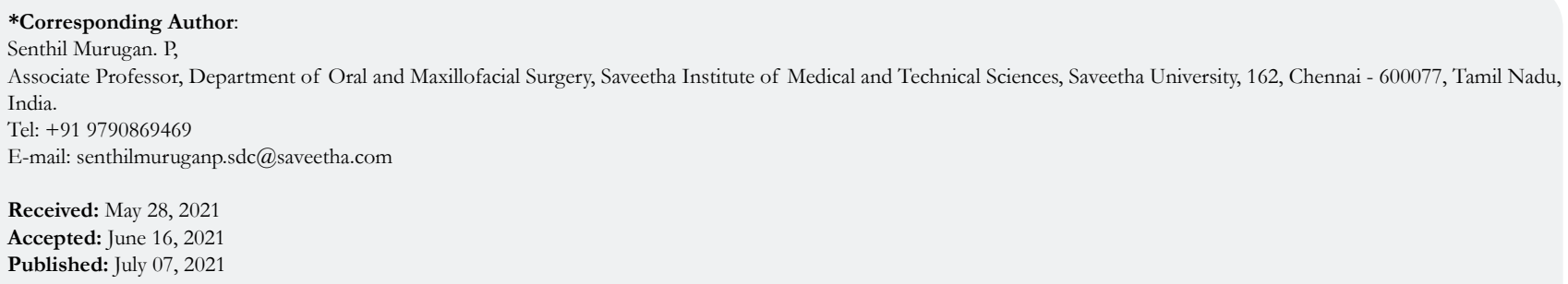

Citation: Aishwarya.S, Senthil Murugan. P, Suresh. V. Comparison of Post Extraction Healing in Diabetic Patients with two different Blood Glucose Levels - A Case Control Study. Int J Dentistry Oral Sci. 2021;8(7):3124-3128. doi: http://dx.doi.org/10.19070/2377-8075-21000636

Copyright: Senthil Murugan. $\mathbf{P}^{\circ}$ 2021. This is an open-access article distributed under the terms of the Creative Commons Attribution License, which permits unrestricted use, distribution and reproduction in any medium, provided the original author and source are credited. 
and extraction sockets in diabetic patients is due to inactive or static blood flow, low growth factors and antibodies production, questionable immunity,poor angiogenesis and psychological stress [27]. This study purely concentrates on diabietic patients with two different blood glucose levels i.e. patients with Blood Glucose Level $<200 \mathrm{mg} / \mathrm{dl}$ and patients with Blood Glucose Level $>200 \mathrm{mg} / \mathrm{dl}$ and the rate of healing of the extraction socket.

Therefore, management and treatment of diabetic patients undergoing oral surgical procedures are more difficult. Delayed angiogenesis, decrease in blood flow, compromised innate immunity, decrease in the production of growth factor and psychological stress have been reported as factors causing delay in the healing of oral ulcers $[3,32]$. In most cases, diabetes makes the patient susceptible to oral and dental problems and complications, including various soft tissue injuries and inflammatory conditions $[26,28]$. Previously our team has a rich experience in working on various research projects across multiple disciplines [18, 21, 47, $14,38,17,46,12,9,34,55,33,45,15,52]$. In this study, we are intended to compare the rate of healing of post extraction sockets among type 1 diabetes patients between two different blood glucose levels.

\section{Materials And Methods}

\section{Study setting}

This study is a university setting, conducted in Saveetha Dental college, Predominantly, the pros of the study include flexibility and less time consumption. The cons of the study is limited to certain populations. 112 Diabetic patients were included in this study. Approval was obtained from the Institutional Ethical Committee [IEC]. The ethical approval number for the present study is SDC/SIHEC/2020/DIASDATA/0619-0320. Two examiners were involved in the study.

\section{Sampling}

The details of the 86,000 patient records were reviewed and analyzed, out of which 112 diabetic patients who had undergone extraction between June 2019 to March 2020 were included in this study. Cross verification of data for error was done by presence of additional reviewers and by photographic evaluation. Simple random sampling was done to minimise the sampling bias. It was generalised to the south Indian population.

\section{Data collection/tabulation}

Records of all patients who had diabetics and underwent extraction were collected from initial to last in the chronological order. The data verification was done based on age, sex, Blood Glucose Level, number of extraction sites and postop review of extracted site for healing were recorded and the data were tabulated. The data was entered in the excel sheet in a methodical manner and was imported to SPSS. Incomplete or censored data was excluded from the study.

\section{Analysis}

IBM SPSS 2.0 software, was used for data analysis Independent variables include age, gender and dependent variable include no of extraction, RBS analysis. Descriptive and inferential statistics were used. Descriptive statistics includes the frequency of distribution of age, sex and inferential statistics includes the chisquare test.

\section{Results}

On analysing the age group, 46 patients who were greater than 60 years had undergone extraction out of which $61.4 \%$ of them had satisfactory healing, $77.8 \%$ of the patients belonging to the age group of 51-60 years had satisfactory healing while $85.19 \%$ of patients who come under 41-50 years have satisfactory healing. From this we can observe that healing occurs at a faster rate in younger diabetic patients when compared to older patients. It is observed that the rate of healing is slower as the age increases in diabetic patient group population. As we can see in the graph, as the age increases, the rate of healing decreases, the bar chart shows gradual increase in the number of unsatisfactory healing with increase in age, It is evident that there is no significant difference between age and rate of healing since there is only diminutive difference in the healing range and age groups.Not statistically significant as Chi square value is 3.530 and $p$ value 0.317 $[\mathrm{P}>0.05]$ [Figure 1].

The relation between gender and healing of socket is given in [ Figure 2]. Out of 63 males, $66.67 \%$ of them showed satisfactory healing likewise out of 42 females, $85.17 \%$ showed satisfactory

Figure 1: The bar chart showing association of age and healing of socket. ( $x$ axis ; age group, $y$ axis : count/rate of healing ).As we can see in the graph, patients aged greater than 60 years who had undergone extraction, $29.5 \%$ of them had satisfactory healing, $20 \%$ of them belonging to the age group of 51-60 years had satisfactory healing while $21.9 \%$ of patients who come under 41-50 years have satisfactory healing.It is evident that there is no significant difference between age and rate of healing since there is only diminutive difference in the healing range and age groups. Not statistically significant as Chi square value is 3.530 and $p$ value 0.317 [P>0.05]

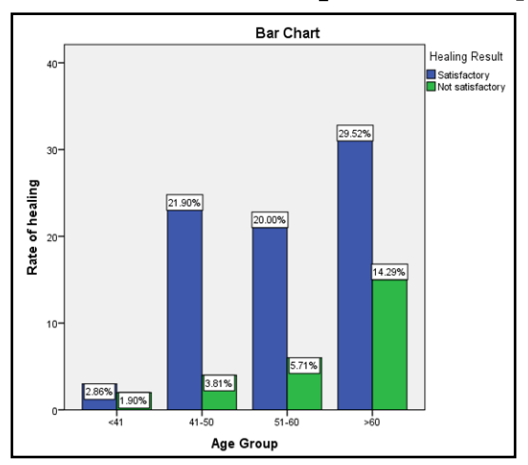


Figure 2. Bar chart showing association of gender and healing of the socket. $\mathrm{X}$ axis represents Gender group and $\mathrm{Y}$ axis represents the healing rate.Out of $60 \%$ of males, $40 \%$ of them showed satisfactory healing and out of $40 \%$ of females $34.29 \%$ showed satisfactory healing. From this we can contemplate that females have a higher healing rate than males. There is a significant difference between gender and healing in diabetic patients which is also statistically significant. $p$ Value 0.029. and chi square value was $4.786[\mathrm{p}<0.05]$.

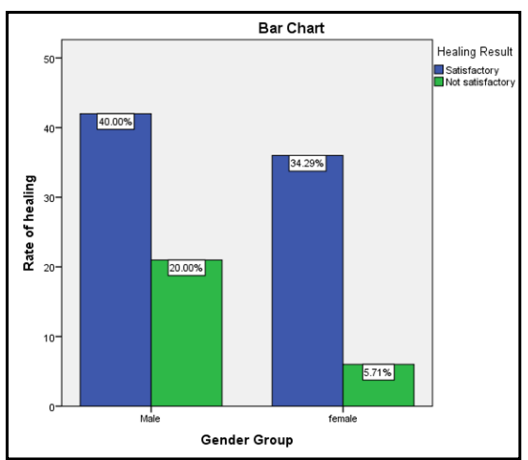

Figure 3. Bar chart represents association between random blood sugar and healing of extraction, we can observe that RBS $<200 \mathrm{mg} / \mathrm{dl}$ had comparatively higher healing than $\mathrm{RBS}>200 \mathrm{mg} / \mathrm{d} 1 . \mathrm{X}$ axis represents the RBS level group and $\mathrm{Y}$ axis rate of healing count. $65.71 \%$ of patients whose Blood Glucose Level is less than $200 \mathrm{mg} / \mathrm{dl}$ had satisfactory healing while only $8.57 \%$ of patients with Blood Glucose level greater than $200 \mathrm{mg} / \mathrm{dl}$ showed satisfactory healing.There is a significant difference between healing of extraction socket and Blood Glucose Level observed in this study as the parameters observed were statistically significant $\mathrm{p}=0.000$ and chi square was $19.05[\mathrm{p}<0.05]$.

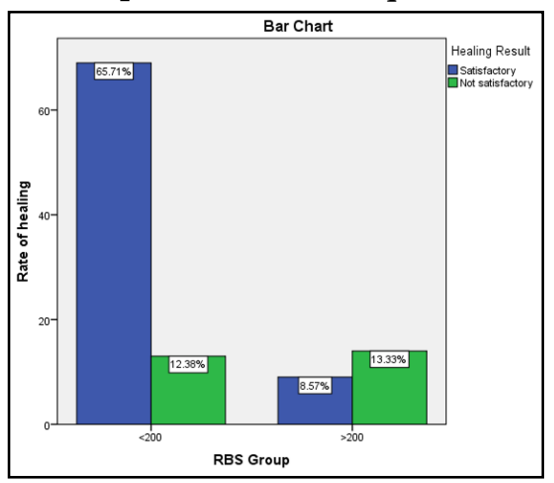

Table 1: The reveals correlation between number of extraction sites and rate of healing. There is no significant difference observed between these two parameters. This finding is not statistically significant as $p$ value 0.594 [p $>0.050$ ]

\begin{tabular}{|c|c|c|c|c|c|}
\hline \multirow{2}{*}{$\begin{array}{c}\text { No of Ex- } \\
\text { tractionGroup }\end{array}$} & \multicolumn{2}{|c|}{ Healing Result } & \multirow{2}{*}{ Total } & \multirow{2}{*}{$\begin{array}{c}\text { Chi square } \\
\text { value }\end{array}$} & \multirow{2}{*}{$P$ value } \\
\hline & Satisfactory & Not satisfactory & & & \\
\hline$<6$ & 68 & 21 & 89 & \multirow{5}{*}{1.896} & \multirow{5}{*}{0.594} \\
\hline $7-12$ & 6 & 4 & 10 & & \\
\hline $13-18$ & 3 & 1 & 4 & & \\
\hline $19-24$ & 1 & 1 & 2 & & \\
\hline Total & 78 & 27 & 105 & & \\
\hline
\end{tabular}

healing. From this we can contemplate that females have a higher healing rate than males. There is a significant difference observed in our study between gender and healing in diabetic patients as the finding is statistically significant $\mathrm{p}<0.05$.

[Table 1] revealed correlation between number of extraction sites and rate of healing. There is no significant difference observed between the number of extraction sites and rate of healing because the finding is not statistically significant $p$ value $>0.050$.

The relationship between the Blood Glucose Level and healing, $84.15 \%$ of patients whose Blood Glucose Level is less than 200 $\mathrm{mg} / \mathrm{dl}$ had satisfactory healing while only $39 \%$ of patients with Blood Glucose level greater than $200 \mathrm{mg} / \mathrm{dl}$ showed satisfactory healing. There is a significant difference between healing and
Blood Glucose Level observed in this study as the parameter observed is statistically significant $[\mathrm{p}<0.05]$ [ Figure 3].

\section{Discussion}

The hyperglycemia in diabetic patients can pave way to reduce leukocyte count and have deleterious effects on vascular epithelium and healing potential [2]. Stratton et al , reported each $1 \%$ decrease in HbA1C level leads to $37 \%$ decrease in micro vascular complications $[\mathrm{P}<0.001]$ [49]. Because of micro vascular and macro vascular changes and immune deficiency in diabetes, risk of infection will increase.

In this study, we can contemplate that there is significant association between the blood glucose level and the rate of healing of 
extraction socket $\mathrm{P}$ value $[<0.05]$. Also it is observed that females had a higher healing rate compared to males and the rate of healing decreases with increase in age.

Infections is the major risk factor for uncontrolled diabetic patients $[43,35]$, the underlying cause of uncontrollable diabetes is still not clear. There are few possible explanations that can resolve these doubts.

a) Insufficient insulin levels can slower the rate of healing $[5,1]$

b) Healing of tooth sockets requires repair and regeneration of tissues, this is controlled and regulated by specific molecules like TGF- B, VEGF, BMP, PGF [9].Uncontrollable diabetes, the healing is prolonged due to delayed onset of cell proliferation and osteoblastic differentiation $[56,46]$.

c) Poor blood circulation is commonly seen in uncontrollable diabetic patients. This leads to delay in delivery of nutrients and oxygenated blood to the surgical site resulting in slower healing rate $[4,29]$.

d) When fasting blood glucose level $>240 \mathrm{mg} / \mathrm{dl}$, the body starts metabolizing fat at a higher rate, converting fatty acids to ketone $[7,38]$. High ketone levels cause diabetic ketoacidosis leading the blood to become acidic. These ketone bodies interfere in the healing process inhibiting the secretion of nitric oxide and macrophages $[31,50,36]$.

Our present study showed that diabetic patients had normal healing in both different blood group levels but the healing occurs at a slower pace in patients with Blood Glucose Level>200 mg/ dl compared to patients with Blood Glucose Level $<200 \mathrm{mg} / \mathrm{dl}$. This result is in consistent with the study conducted by Huang et al, where he determined differences in wound healing in Type II diabetic patients and reported that healing is normal after the tooth extraction [1].

The study conducted by Jarbassiet al, have also reported that diabetic patients with high Blood Glucose Level showed lack of healing at the end of 7 th day, however there was no abnormalities or complications seen in the patients [2]. However we cannot completely neglect the risk of complications of post extraction in diabetic patients.Devlin et al ,reported that blood clot in uncontrolled diabetic patients are weaker leading to more chance of alveolar destruction [11, 52] Our institution is passionate about high quality evidence based research and has excelled in various fields $[53,37,40,39,48,13,25,44,42,8,54]$.

\section{Conclusion}

In this study we can contemplate that healing of the extraction socket occurs at a slower pace in patients with Blood Glucose Level $>200 \mathrm{mg} / \mathrm{dl}$ compared to patients with Blood Glucose Level $<200 \mathrm{mg} / \mathrm{dl}$. However there were no complications in post extractions were noted.However a surgeon needs to always be aware of postoperative complications in extraction sockets healing such as alveolar osteitis [dry socket] ,cellulitis, gangrenous osteitis ,suppurative osteitis and osteomyelitis and more importantly mucormycosis which may be fatal if not intervened immediately.

\section{References}

[1]. Abhinav RP, Selvarasu K, Maheswari GU, Taltia AA. The patterns and etiol- ogy of maxillofacial trauma in South India. Ann. Maxillofac. Surg. 2019 Jan;9(1):114-17.

[2]. Akhavan Karbassi MH, Salehi R, Kheirollahi K, Ghaffari Targhi M, Jalili Sadrabad M, Yousefipour B. The relationship between socket blood sugar and post-extraction complications in type II diabetic and non-diabetic patients. Iran. j. diabetes obes. 2015 Mar 10;7(1):12-9.

[3]. Al-Maskari AY, Al-Maskari MY, Al-Sudairy S. Oral manifestations and complications of diabetes mellitus: a review. Sultan Qaboos Univ. Med. J.. 2011 May;11(2):179.

[4]. Arda E, Ay A, Akdere H, Akdeniz E. The association of Intron 4 VNTR and Glu298Asp polymorphisms of the nitric oxide synthetase 3 gene and vasculogenic erectile dysfunction in Turkish men. Syst Biol Reprod Med. 2019 Oct;65(5):383-389.Pubmed PMID: 30977424.

[5]. Aronovich S, Skope LW, Kelly JP, Kyriakides TC. The relationship of glycemic control to the outcomes of dental extractions. J. Oral Maxillofac. Surg. 2010 Dec 1;68(12):2955-61.

[6]. Babineau TJ, Bothe Jr A. General surgery considerations in the diabetic patient. Infect. Dis. Clin. North Am. 1995 Mar 1;9(1):183-93.

[7]. Bailey TS, Grunberger G, Bode BW. American College of Endocrinology 2016 outpatient glucose monitoring consensus statement. Endocr Pract. $2016 \mathrm{Feb} ; 22(2): 231-61$.

[8]. Chandrasekar R, Chandrasekhar S, Sundari KKS, Ravi P. Development and validation of a formula for objective assessment of cervical vertebral bone age. Prog Orthod. 2020 Oct 12;21(1):38.Pubmed PMID: 33043408.

[9]. Choudhari S, Thenmozhi MS. Occurrence and Importance of Posterior Condylar Foramen. Res J Pharm Technol. 2016;9(8):11-43.

[10]. Christabel A, Anantanarayanan P, Subash P, Soh CL, Ramanathan M, Muthusekhar MR, et al. Comparison of pterygomaxillary dysjunction with tuberosity separation in isolated Le Fort I osteotomies: a prospective, multi-centre, triple-blind, randomized controlled trial. Int J Oral Maxillofac Surg. 2016 Feb;45(2):180-5.Pubmed PMID: 26338075.

[11]. Devlin H, Garland H, Sloan P. Healing of tooth extraction sockets in experimental diabetes mellitus. J. Oral Maxillofac. Surg. 1996 Sep 1;54(9):108791.

[12]. Dhinesh B, Lalvani JI, Parthasarathy M, Annamalai K. An assessment on performance, emission and combustion characteristics of single cylinder diesel engine powered by Cymbopogon flexuosus biofuel. Energy Convers. Manag. 2016 Jun 1;117(June):466-74.

[13]. Ezhilarasan D, Apoorva VS, Ashok Vardhan N. Syzygium cumini extract induced reactive oxygen species-mediated apoptosis in human oral squamous carcinoma cells. J Oral Pathol Med. 2019 Feb;48(2):115-121.Pubmed PMID: 30451321.

[14]. Felicita AS. Orthodontic extrusion of Ellis Class VIII fracture of maxillary lateral incisor - The sling shot method. Saudi Dent J. 2018 Jul;30(3):265269.Pubmed PMID: 29942113.

[15]. Govindaraju L, Gurunathan D. Effectiveness of Chewable Tooth Brush in Children-A Prospective Clinical Study. J Clin Diagn Res. 2017 Mar;11(3):ZC31-ZC34.Pubmed PMID: 28511505.

[16]. Gupta B. Assessment of post-operative wound healing in diabetic patients after extraction. Int. J. Adv. Sci. Res. 2017;3(7):77-81.

[17]. Gurunathan D, Shanmugaavel AK. Dental neglect among children in Chennai. J Indian Soc Pedod Prev Dent. 2016 Oct 1;34(4):364.

[18]. Hafeez N. Accessory foramen in the middle cranial fossa. Res J Pharm Technol. 2016;9(11):1880-2.

[19]. Huang S, Dang H, Huynh W, Sambrook PJ, Goss AN. The healing of dental extraction sockets in patients with Type 2 diabetes on oral hypoglycaemics: a prospective cohort. Aust Dent J. 2013 Mar;58(1):89-93.Pubmed PMID: 23441797.

[20]. Jesudasan JS, Wahab PU, Sekhar MR. Effectiveness of $0.2 \%$ chlorhexidine gel and a eugenol-based paste on postoperative alveolar osteitis in patients having third molars extracted: a randomised controlled clinical trial. $\mathrm{Br} \mathrm{J}$ Oral Maxillofac Surg. 2015 Nov;53(9):826-30.Pubmed PMID: 26188932.

[21]. Krishnan RP, Ramani P, Sherlin HJ, Sukumaran G, Ramasubramanian A, Jayaraj G, et al. Surgical Specimen Handover from Operation Theater to Laboratory: A Survey. Ann Maxillofac Surg. 2018 Jul-Dec;8(2):234-238. Pubmed PMID: 30693238.

[22]. Kumar S, Rahman R. Knowledge, awareness, and practices regarding biomedical waste management among undergraduate dental students. Asian J. Pharm. Clin. Res. 2017;10(8):341.

[23]. Sneha S. Knowledge and awareness regarding antibiotic prophylaxis for infective endocarditis among undergraduate dental students. Asian J. Pharm. Clin. Res. 2016 Oct 1:154-9.

[24]. Marimuthu M, Andiappan M, Wahab A, Muthusekhar MR, Balakrishnan A, Shanmugam S. Canonical Wnt pathway gene expression and their clinical correlation in oral squamous cell carcinoma. Indian J. Dent. Res. 2018 May 1;29(3):291-97.

[25]. Mathew MG, Samuel SR, Soni AJ, Roopa KB. Evaluation of adhesion of 
Streptococcus mutans, plaque accumulation on zirconia and stainless steel crowns, and surrounding gingival inflammation in primary molars: randomized controlled trial. Clin Oral Investig. 2020 Sep;24(9):1-6.Pubmed PMID: 31955271

[26]. Mohsin SF, Ahmed SA, Fawwad A, Basit A. Prevalence of oral mucosal alterations in type 2 diabetes mellitus patients attending a diabetic center. Pak J Med Sci. 2014 Jul;30(4):716-9.Pubmed PMID: 25097503.

[27]. Mozzati M, Gallesio G, di Romana S, Bergamasco L, Pol R. Efficacy of plasma-rich growth factor in the healing of postextraction sockets in patients affected by insulin-dependent diabetes mellitus. J Oral Maxillofac Surg. 2014 Mar;72(3):456-62.Pubmed PMID: 24342581

[28]. MP SK. Relationship between dental anxiety and pain experience during dental extractions. Asian J. Pharm. Clin. Res.. 2017 Mar 1:458-61.

[29]. Kumar S. The emerging role of botulinum toxin in the treatment of orofacial disorders: Literature update. Asian J. Pharm. Clin. Res. 2017;10(9):21.

[30]. Kumar S, Rahman R. Knowledge, awareness, and practices regarding biomedical waste management among undergraduate dental students. Asian J. Pharm. Clin. Res. 2017;10(8):341.

[31]. Noh HS, Kim DW, Cho GJ, Choi WS, Kang SS. Increased nitric oxide caused by the ketogenic diet reduces the onset time of kainic acid-induced seizures in ICR mice. Brain Res. 2006 Feb 23;1075(1):193-200.Pubmed PMID: 16460714 .

[32]. Packiri S, Gurunathan D, Selvarasu K. Management of paediatric oral ranula: a systematic review. J. Clin. Diagnostic Res. 2017 Sep;11(9):ZE06-09.

[33]. Palati S, Ramani P, Shrelin HJ, Sukumaran G, Ramasubramanian A, Don $\mathrm{KR}$, et al. Knowledge, Attitude and practice survey on the perspective of oral lesions and dental health in geriatric patients residing in old age homes. Indian J Dent Res. 2020 Jan-Feb;31(1):22-25.Pubmed PMID: 32246676.

[34]. Paramasivam A, Vijayashree Priyadharsini J, Raghunandhakumar S. N6adenosine methylation (m6A): a promising new molecular target in hypertension and cardiovascular diseases. Hypertens Res. 2020 Feb;43(2):153154.Pubmed PMID: 31578458.

[35]. Patil SB, Durairaj D, Suresh Kumar G, Karthikeyan D, Pradeep D. Comparison of Extended Nasolabial Flap Versus Buccal Fat Pad Graft in the Surgical Management of Oral Submucous Fibrosis: A Prospective Pilot Study. J Maxillofac Oral Surg. 2017 Sep;16(3):312-321.Pubmed PMID: 28717289.

[36]. Patturaja K, Pradeep D. Awareness of Basic Dental Procedure among General Population. Res J Pharm Technol . 2016;9(9):1349-51.

[37]. Pc J, Marimuthu T, Devadoss P, Kumar SM. Prevalence and measurement of anterior loop of the mandibular canal using CBCT: A cross sectional study. Clin Implant Dent Relat Res. 2018 Apr 6;20(4):531-4.

[38]. Rahman R. Knowledge, Attitude And Awareness Of Dental Undergraduate Students Regarding Hiv/Aids Patients. Asian J. Pharm. Clin. Res. 2017 May $1: 175-80$.

[39]. Ramadurai N, Gurunathan D, Samuel AV, Subramanian E, Rodrigues SJ. Effectiveness of $2 \%$ Articaine as an anesthetic agent in children: randomized controlled trial. Clin Oral Investig. 2019 Sep;23(9):3543-50.

[40]. Ramesh A, Varghese S, Jayakumar ND, Malaiappan S. Comparative estimation of sulfiredoxin levels between chronic periodontitis and healthy patients - A case-control study. J Periodontol. 2018 Oct;89(10):1241-1248.Pubmed PMID: 30044495.

[41]. Retzepi M, Lewis MP, Donos N. Effect of diabetes and metabolic control on de novo bone formation following guided bone regeneration. Clin. Oral Implants Res. 2010 Jan;21(1):71-9.

[42]. R H, Ramani P, Ramanathan A, R JM, S G, Ramasubramanian A, et al. CYP2 C9 polymorphism among patients with oral squamous cell carcinoma and its role in altering the metabolism of benzo[a]pyrene. Oral Surg Oral
Med Oral Pathol Oral Radiol. 2020 Sep;130(3):306-312.Pubmed PMID: 32773350.

[43]. Saeb ATM, Al-Rubeaan KA, Aldosary K, Udaya Raja GK, Mani B, Abouelhoda M, et al. Relative reduction of biological and phylogenetic diversity of the oral microbiota of diabetes and pre-diabetes patients. Microb Pathog. 2019 Mar;128:215-229.Pubmed PMID: 30625362.

[44]. Samuel SR. Can 5-year-olds sensibly self-report the impact of developmental enamel defects on their quality of life? Int J Paediatr Dent. 2021 Mar;31(2):285-286.Pubmed PMID: 32416620.

[45]. Saravanan M, Arokiyaraj S, Lakshmi T, Pugazhendhi A. Synthesis of silver nanoparticles from Phenerochaete chrysosporium (MTCC-787) and their antibacterial activity against human pathogenic bacteria. Microb Pathog. 2018 Apr;117:68-72.Pubmed PMID: 29427709.

[46]. Sneha S. Knowledge and awareness regarding antibiotic prophylaxis for infective endocarditis among undergraduate dental students. Asian J. Pharm. Clin. Res. 2016 Oct 1:154-9.

[47]. Somasundaram S, Ravi K, Rajapandian K, Gurunathan D. Fluoride Content of Bottled Drinking Water in Chennai, Tamilnadu. J Clin Diagn Res. 2015 Oct;9(10):ZC32-4.Pubmed PMID: 26557612.

[48]. Sridharan G, Ramani P, Patankar S, Vijayaraghavan R. Evaluation of salivary metabolomics in oral leukoplakia and oral squamous cell carcinomaJ. Oral Pathol. Med. 2019 Apr;48(4):299-306.

[49]. Stratton IM, Adler AI, Neil HA, Matthews DR, Manley SE, Cull CA, et al. Association of glycaemia with macrovascular and microvascular complications of type 2 diabetes (UKPDS 35): prospective observational study. BMJ. 2000 Aug 12;321(7258):405-12.Pubmed PMID: 10938048.

[50]. Sweta VR, Abhinav RP, Ramesh A. Role of Virtual Reality in Pain Perception of Patients Following the Administration of Local Anesthesia. Ann Maxillofac Surg. 2019 Jan-Jun;9(1):110-113.Pubmed PMID: 31293937.

[51]. Vestergaard P. Discrepancies in bone mineral density and fracture risk in patients with type 1 and type 2 diabetes--a meta-analysis. Osteoporos Int. 2007 Apr;18(4):427-44.Pubmed PMID: 17068657.

[52]. Vijayakumar Jain S, Muthusekhar MR, Baig MF, Senthilnathan P, Loganathan S, Abdul Wahab PU, et al. Evaluation of Three-Dimensional Changes in Pharyngeal Airway Following Isolated Lefort One Osteotomy for the Correction of Vertical Maxillary Excess: A Prospective Study. J Maxillofac Oral Surg. 2019 Mar;18(1):139-146.Pubmed PMID: 30728705.

[53]. Vijayashree Priyadharsini J. In silico validation of the non-antibiotic drugs acetaminophen and ibuprofen as antibacterial agents against red complex pathogens. J Periodontol. 2019 Dec;90(12):1441-1448.Pubmed PMID: 31257588.

[54]. Vijayashree Priyadharsini J, Smiline Girija AS, Paramasivam A. In silico analysis of virulence genes in an emerging dental pathogen A. baumannii and related species. Arch Oral Biol. 2018 Oct;94:93-98.Pubmed PMID: 30015217.

[55]. Wu F, Zhu J, Li G, Wang J, Veeraraghavan VP, Krishna Mohan S, et al. Biologically synthesized green gold nanoparticles from Siberian ginseng induce growth-inhibitory effect on melanoma cells (B16). Artif Cells Nanomed Biotechnol. 2019 Dec;47(1):3297-3305.Pubmed PMID: 31379212.

[56]. Younis WH, Al-Rawi NH, Mohamed MA, Yaseen NY. Molecular events on tooth socket healing in diabetic rabbits. Br J Oral Maxillofac Surg. 2013 Dec;51(8):932-6.Pubmed PMID: 24125632.

[57]. Zhang Z, Fang P, Yu M, Wang Y, Li Y, Shi M, et al. Serum galanin concentration is increased in subjects with impaired glucose tolerance. Can. J. Diabetes. 2017 Dec 1;41(6):563-6. 